\title{
In vivo antithrombotic properties of a heparin from the oocyte test cells of the sea squirt Styela plicata (Chordata-Tunicata)
}

\section{Cardilo-Reis*, M.C.M. Cavalcante*, C.B.M. Silveira and M.S.G. Pavão}

\author{
Laboratório de Tecido Conjuntivo, Hospital Universitário Clementino Fraga Filho \\ and Programa de Glicobiologia, Instituto de Bioquímica Médica, \\ Universidade Federal do Rio de Janeiro, Rio de Janeiro, RJ, Brasil
}

\author{
Correspondence \\ M.S.G. Pavão \\ Instituto de Bioquímica Médica \\ CCS, UFRJ \\ 21941-590 Rio de Janeiro, RJ \\ Brasil \\ Fax: +55-21-2562-2090 \\ E-mail: mpavao@hucff.ufrj.br \\ *These authors contributed \\ equally to this study. \\ Research supported by CNPq, FAPERJ \\ and the NIH Fogarty International \\ Center (R03 TW05775). M.S.G. Pavão \\ is the recipient of a research \\ fellowship from $\mathrm{CNPq}$.
}

Received February 16, 2006 Accepted August 3, 2006

\begin{abstract}
In the ascidian Styela plicata, the oocytes are surrounded by two types of accessory cells named follicle cells and test cells. A heparin-like substance with an anticoagulant activity equivalent to $10 \%$ of mammalian heparin and about $5 \%$ as potent as the mammalian counterpart for the inhibition of thrombin by antithrombin was isolated from the oocyte test cells. In the present study, we compared the antithrombotic and hemorrhagic effects of sea squirt oocyte test cell heparin with those of porcine heparin in rat models of venous thrombosis and blood loss. Intravenous administration of the oocyte test cell heparin to Wistar rats (both sexes, weighing $\sim 300 \mathrm{~g}, \mathrm{~N}=4$ in each group) at a dose of $5.0 \mathrm{mg} / \mathrm{kg}$ body weight, which produced a 1.8 -fold increase in plasma activated partial thromboplastin time, inhibited thrombosis by $45 \pm 13.5 \%$ (mean $\pm \mathrm{SD}$ ) without any bleeding effect. The same dose of porcine heparin inhibited thrombosis by $100 \pm 1.4 \%$, but produced a blood loss three times greater than that of the saline-treated control. However, 10-fold reduction of the dose of porcine heparin to $0.5 \mathrm{mg} /$ $\mathrm{kg}$ body weight, which produced a 5 -fold increase in plasma-activated partial thromboplastin time, inhibited thrombosis by $70 \pm 13 \%$ without any bleeding effect. The antithrombotic properties of a new heparin isolated from test cells of the sea squirt $S$. plicata, reported here for the first time, indicate that, although sea squirt oocyte test cell heparin was a poor anticoagulant compared to porcine heparin, it had a significant antithrombotic effect without causing bleeding.
\end{abstract}

Key words - Ascidian

- Heparin

- Experimental thrombosis

- Antithrombotics

- Hemorrhage

\section{Introduction}

Heparin is a highly sulfated glycosaminoglycan composed of disaccharide repeats of hexuronic acid ( $\alpha$-L-iduronic acid or B-Dglucuronic acid) linked 1,4 to $\alpha$-D-glucosamine. Heparin is a heterogeneous mixture of polymers with a similar backbone. The heterogeneity results from variations of D-glucosamine sulfation ( $\mathrm{N}$-acetylated, $\mathrm{N}$-sulfated, O-sulfated at C6 and/or C3) and of the uronic acid residue (O-sulfated or not at C2) (1).

Because of its binding to antithrombin by means of a specific pentasaccharide sequence 
[GlcNAc $\left(6 \mathrm{SO}_{4}\right)$-GlcA-GlcNS( $\left.3 \mathrm{SO}_{4}\right)$-IdoA $\left.\left(2 \mathrm{SO}_{4}\right)-\mathrm{GlcNS}\left(6 \mathrm{SO}_{4}\right)\right]$ (2), heparin has a potent anticoagulant activity (3). In the presence of heparin, the rates of inhibition of thrombin, factor IXa, and factor Xa by antithrombin are increased 1000-fold (4), so that inhibition is essentially instantaneous. Heparin has been used clinically for almost 70 years for the prevention of thromboembolic events frequently observed after surgery, especially pelvic and orthopedic surgery $(5,6)$.

In vertebrates, heparin is present in secretory granules of mast cells and basophils and is released only when mast cells degranulate in response to extracellular signals $(1,2,7)$. Among invertebrates, heparins with different structures, molecular weights and anticoagulant activity have been reported in mollusks, crustacean and annelid (8-11). More recently, a heparin with structure similar to the mammalian counterpart, but with differences in the degree of sulfation has been identified in the intracellular granules of oocyte test cells of the ascidian (commonly known as sea squirt) Styela plicata (12). Oocyte test cells are accessory cells located in the perivitelline space of ascidian oocytes, where they remain during egg development until hatching. Sea squirt oocyte test cell heparin is composed mainly of the disaccharide [ $\alpha$-L-IdoA $\left(2 \mathrm{SO}_{4}\right)-1 \rightarrow 4 \beta-\mathrm{D}$ $\left.\mathrm{GlcN}\left(\mathrm{SO}_{4}\right)\left(6 \mathrm{SO}_{4}\right)-1\right] \mathrm{n}$, similar to mammalian heparin. About $25 \%$ of the disaccharide $\left[\alpha\right.$-L-IdoA- $\left.1 \rightarrow 4 \beta-\mathrm{D}-\mathrm{GlcN}\left(\mathrm{SO}_{4}\right)\left(6 \mathrm{SO}_{4}\right)-1\right] \mathrm{n}$ is also present (12). When compared to mammalian heparin, sea squirt oocyte test cell heparin has $10 \%$ of its anticoagulant activity measured by activated partial thromboplastin time (aPTT). In addition, it is about $5 \%$ as potent as the mammalian counterpart for the inhibition of thrombin by antithrombin. However, it activates heparin co-factor II (HCII) to the same extent as mammalian heparin, as indicated by the $\mathrm{IC}_{50}$ for thrombin inhibition in the presence of the inhibitor HCII (12). The prevalence of trisulfated disaccharides containing iduronic acid and N-sulfated glucosamine, the lack of glucuronic acid and $\mathrm{N}$ acetylgalactosamine-containing disaccharides, the antithrombin-mediated thrombin inhibitory activity, and the intracellular localization of the ascidian glycosaminoglycan clearly demonstrate that sea squirt oocyte test cell heparin belongs to the heparin family.

In the present study, we compared the antithrombotic and hemorrhagic effects of sea squirt oocyte test cell and porcine heparins in vivo using rat models. We showed that the oocyte test cell heparin has a lower but significant antithrombotic activity and a lower bleeding effect when compared to porcine heparin.

\section{Material and Methods}

\section{Extraction and purification of the test cell heparin}

Adult specimens of S. plicata were collected from Guanabara Bay, Rio de Janeiro, RJ, Brazil, and maintained in an aerated aquarium. The gonads of several ascidians were carefully separated from other tissues under magnifying lenses, and the eggs isolated as described (12). The glycosaminoglycans were extracted from the eggs by papain digestion and ethanol precipitation and the heparin was purified by anion-exchange chromatography on a Mono Q column (Amersham Biosciences, São Paulo, SP, Brazil) as described (12).

\section{Inhibition of factor Xa by antithrombin in the presence of sea squirt oocyte test cell heparin}

The inhibition of factor Xa by the sea squirt oocyte test cell heparin in the presence of antithrombin was measured by an amylolytic activity assay using a chromogenic substrate (12). Incubations were performed in disposable UV semi-microcuvettes. The 
final concentrations of reactants included $50 \mathrm{nM}$ human antithrombin (Haematologic Technologies Inc., Essex Junction, VT, USA), $15 \mathrm{nM}$ human factor Xa (Haematologic Technologies) and $0-1000 \mu \mathrm{g} / \mathrm{mL}$ heparin in $100 \mu \mathrm{L} 20 \mathrm{mM}$ Tris/HCl, $0.15 \mathrm{M}$ $\mathrm{NaCl}$, and $1.0 \mathrm{mg} / \mathrm{mL}$ polyethylene glycol, pH 7.4 (Tris/PEG buffer). Factor Xa was added to initiate the reaction. After $60 \mathrm{~s}$ at room temperature, $500 \mu \mathrm{L} 100 \mu \mathrm{M}$ N-methoxycarbonyl-D-norleucyl-glycyl-L-arginine4-nitranillide-acetate (Roche, Mannheim, Germany) in Tris/PEG buffer was added and absorbance at $405 \mathrm{~nm}$ was measured for 100 s. The rate of change of absorbance was proportional to the amount of factor Xa activity remaining in the incubation mixture. No inhibition occurred in control experiments in which factor Xa was incubated with antithrombin in the absence of heparin, nor did inhibition occur when factor Xa was incubated with heparin alone in the concentration range tested. Porcine intestinal mucosa heparin (porcine-Hep, 180 units/mg; Sigma-Aldrich, St. Louis, MO, USA) and Nadroparin (average anti-Xa activity 112 units/mg; Sanofi, Vitry-sur Seine, France) were used as standards.

\section{Animal procedures}

The animal studies were carried out in accordance with the Brazilian Animal Protection Law and the Institutional Guidelines for Animal Care and Experimentation.

\section{Ex-vivo anticoagulant action measured by activated partial thromboplastin time}

The effect of sea squirt oocyte test cell heparin on coagulation was determined in Wistar rats (both sexes, $\sim 300 \mathrm{~g}$ body weight) anesthetized with an intramuscular injection of $100 \mathrm{mg} / \mathrm{kg}$ ketamine (Cristália, São Paulo, $\mathrm{SP}$, Brazil) and $16 \mathrm{mg} / \mathrm{kg}$ xylazine (Bayer S/ A, São Paulo, SP, Brazil), and supplemented as needed. The right carotid artery was iso- lated and cannulated with a 22-gauge catheter (Jelco, Johnson \& Johnson Medical Ltda., São José dos Campos, SP, Brazil) for blood collection and administration of the heparin. Blood $(\sim 500 \mu \mathrm{L})$ was collected into $2.8 \%$ sodium citrate $(9: 1, \mathrm{v} / \mathrm{v})$ for aPTT determination before and 10, 20, 30, 40, 50, and $60 \mathrm{~min}$ after intravenous administration in a bolus of $0.5 \mathrm{mg} / \mathrm{kg}$ of porcine heparin or $5 \mathrm{mg} / \mathrm{kg}$ of sea squirt oocyte test cell heparin. At least 4 animals were used in each group.

\section{In vivo antithrombotic effect}

Antithrombotic activity was measured in rats using rabbit brain thromboplastin (bioMérieux Brazil, Rio de Janeiro, RJ, Brazil) as the stimulus (13). Briefly, Wistar rats (both sexes, $\sim 300 \mathrm{~g}$ body weight) were anesthetized with an intramuscular injection of $100 \mathrm{mg} / \mathrm{kg}$ body weight of ketamine (Cristália) and $16 \mathrm{mg} / \mathrm{kg}$ body weight of xylazine (Bayer S/A). The abdomen of each animal was opened and the vena cava was carefully dissected. A segment of $0.7 \mathrm{~cm}$ was prepared beginning just below the branch of the right renal vein up to and beyond the left renal vein, which was ligated. Porcine heparin (Sigma-Aldrich, 180 units/mg) or sea squirt oocyte test cell heparin at the doses of 0.5 and $5 \mathrm{mg} / \mathrm{kg}$ was administered intravenously $2.0 \mathrm{~cm}$ below the distal loose suture and allowed to circulate for $5 \mathrm{~min}$. Then, brain thromboplastin (Biolab-Mérieux AS, Rio de Janeiro, RJ, Brazil; $5 \mathrm{mg} / \mathrm{kg}$ body weight) was injected slowly intravenously $1.0 \mathrm{~cm}$ below the distal loose suture and the venous segment was then clamped, first at the level of the proximal suture and then at the level of the distal suture. After 20 min of stasis, the thrombus formed in the occluded segment was washed with $5 \%$ sodium citrate, dried for $1 \mathrm{~h}$ at $60^{\circ} \mathrm{C}$ and weighed. At least 4 animals per group were used. Mean thrombus weight was obtained for each group and is reported as percent of the weight of 
the thrombus in the absence of heparin.

\section{Bleeding}

The bleeding effect was determined in Wistar rats (both sexes, $\sim 300 \mathrm{~g}$ body weight) anesthetized with a combination of xylazine and ketamine, as described above. A cannula was inserted into the right carotid artery

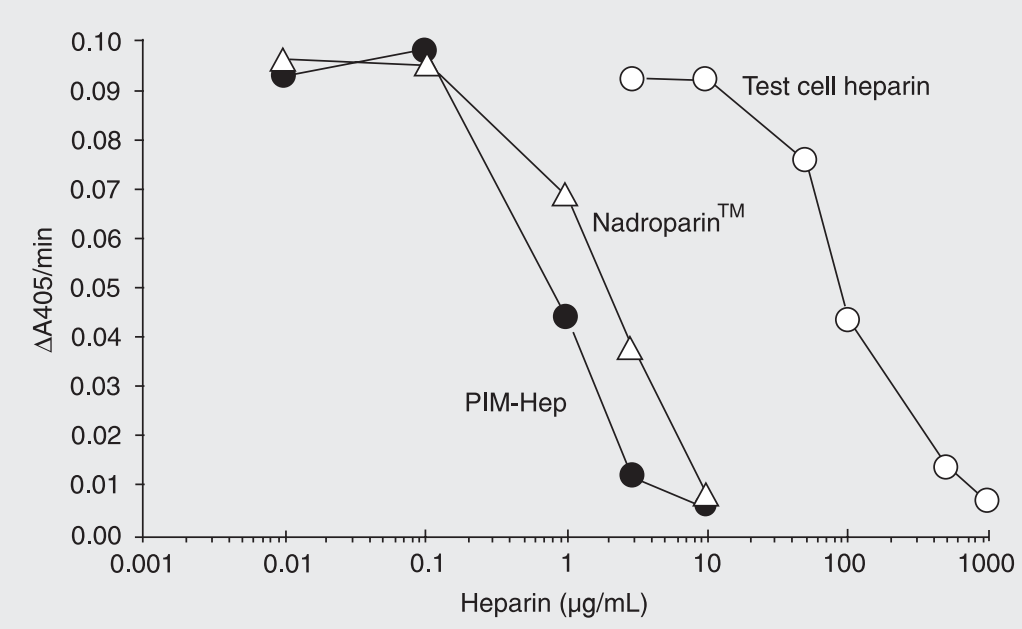

Figure 1. Anti-factor Xa properties of porcine and oocyte test cell heparin. Human antithrombin $(50 \mathrm{nM})$ was incubated with human factor Xa $(15 \mathrm{nM})$ in the presence of 0 to $1000 \mu \mathrm{g} / \mathrm{mL}$ of the different heparins. After $60 \mathrm{~s}$, the remaining factor Xa activity was determined with the chromogenic substrate $\mathrm{N}$-methoxycarbonyl-D-norleucyl-glycyl-L-arginine-4-nitranillide-acetate $(100 \mu \mathrm{M})$ and absorbance at $405 \mathrm{~nm}$ was recorded for $100 \mathrm{~s}(\Delta \mathrm{A} 405 / \mathrm{min})$. PIM-Hep $=$ porcine heparin (filled circles), Nadroparin (triangles), oocyte test cell heparin (open circles). Results represent the average of two separate experiments.

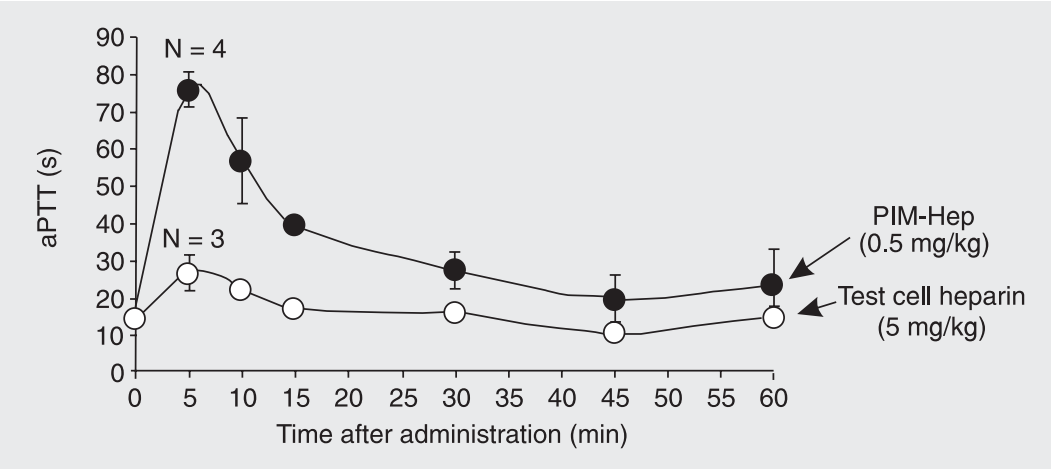

Figure 2. Anticoagulant effect of porcine heparin (PIM-Hep) and oocyte test cell heparin. Blood $(\sim 500 \mu \mathrm{L})$ was collected into $2.8 \%$ sodium citrate $(9: 1, \mathrm{v} / \mathrm{v})$ before and after intravascular administration in a bolus of $0.5 \mathrm{mg} / \mathrm{kg}$ body weight porcine heparin (filled circles) or 5.0 $\mathrm{mg} / \mathrm{kg}$ body weight of test cell heparin (open circles). Activated partial thromboplastin time (aPTT; mean \pm SD) was determined for ex vivo rat plasma as described in Material and Methods. Error bars were omitted when they were less than the size of the symbol. for the administration of heparin $(0.5$ or 5.0 $\mathrm{mg} / \mathrm{kg}$ ). After $5 \mathrm{~min}$ the rat tail was cut $3 \mathrm{~mm}$ from the tip and carefully immersed in 40 $\mathrm{mL}$ distilled water at room temperature. Blood was collected for $60 \mathrm{~min}$ and the blood loss measured on the basis of hemoglobin content of the water solution by spectrophotometry (14). The volume of blood was deduced from a standard curve based on blood dilution by absorbance at $540 \mathrm{~nm}$. At least 4 animals were used per group.

\section{Statistical analysis}

Data are reported as means $\pm \mathrm{SD}$. Comparisons between two groups were made by the $t$-test and the differences were considered significant when $\mathrm{P}<0.05$.

\section{Results}

\section{Anti-factor Xa activity of oocyte test cell heparin}

The data in Figure 1 show that the antifactor Xa activity of the ascidian heparin is equivalent to $1.1 \%$ of porcine heparin and $40 \%$ of Nadroparin, based on total weight. The $\mathrm{IC}_{50}$ for factor Xa inhibition by antithrombin, estimated by the curves in Figure 1 , was about $1.0,2.5$, and $90 \mu \mathrm{g} / \mathrm{mL}$ for porcine heparin, nadroparin and test cellheparin, respectively.

\section{In vivo anticoagulant effect}

Figure 2 shows that aPTT increased up to $\sim 5$-fold during the first $5 \mathrm{~min}$ after injection of porcine heparin. After $5 \mathrm{~min}$, aPTT started to decrease and remained 2-fold higher than the control value for the next $60 \mathrm{~min}$. Oocyte test cell heparin induced a less intense change in aPTT values, with a maximum increase of 1.8fold at $5 \mathrm{~min}$, returning to normal after $15 \mathrm{~min}$. No significant change in aPTT was observed after the administration of test cell heparin doses lower than $5 \mathrm{mg} / \mathrm{kg}$ (data not shown). 


\section{Effect on thrombosis}

The effect of ascidian and mammalian heparins on thrombosis was investigated using an experimental venous thrombosis model in rats. A single injection of $0.5 \mathrm{mg} / \mathrm{kg}$ of porcine heparin in a bolus, given $5 \mathrm{~min}$ before the thrombogenic stimulus with rabbit brain thromboplastin induced about $70 \%$ inhibition of thrombosis (Figure 3). Administration of the same dose of oocyte test cell heparin did not produce any inhibition of thrombosis (Figure 3). Porcine heparin administered at $5 \mathrm{mg} / \mathrm{kg}$ produced $100 \%$ inhibition of thrombosis, whereas the same dose of oocyte test cell heparin reduced thrombosis by only $45 \%$. We also evaluated the effect of the mammalian and ascidian heparins on thrombosis at the dose of $2.0 \mathrm{mg} / \mathrm{kg}$. At this dose, porcine heparin inhibited thrombosis by $100 \%$, whereas oocyte test cell heparin had no effect (data not shown).

\section{Hemorrhagic effect}

The hemorrhagic effect of porcine and oocyte test cell heparins was assessed after intravascular administration based on blood loss in a rat cut-tail bleeding assay. At the antithrombotic dose of $5 \mathrm{mg} / \mathrm{kg}$ body weight, oocyte test cell heparin did not modify the blood loss compared with rats receiving saline (Table 1). The blood loss increased 2.6fold in rats receiving the same dose of porcine heparin (Table 1). The dose of porcine heparin needed to achieve $70 \%$ inhibition of thrombosis $(0.5 \mathrm{mg} / \mathrm{kg})$ did not increase the blood loss.

\section{Discussion}

In a previous study, heparin with a different sulfation pattern and anticoagulant activity was isolated from the oocyte test cells of the ascidian $S$. plicata (12). Here we assessed the antithrombotic and bleeding effects of this heparin after intravascular ad- ministration to rats, using experimental models of venous thrombosis and bleeding.

The anti-factor Xa activity of the test cell heparin was about 40 times lower than that of a low-molecular weight heparin (Nadroparin), which has an average anti-factor $\mathrm{Xa}$ activity of 112 units/mg. Therefore, the antifactor Xa of the oocyte test cell heparin can be estimated to be about 2.8 units $/ \mathrm{mg}$. The anticoagulant activity obtained by the in $v i$ tro experiments reported here (Figure 1) and in the previous study (12) agrees with the results obtained in in vivo experiments (Figure 2), showing that the oocyte test cell heparin has a very low anticoagulant activity. A dose of $5 \mathrm{mg} / \mathrm{kg}$ body weight of the oocyte test cell heparin is required to produce a 1.8-fold increase in aPTT in rat plasma.

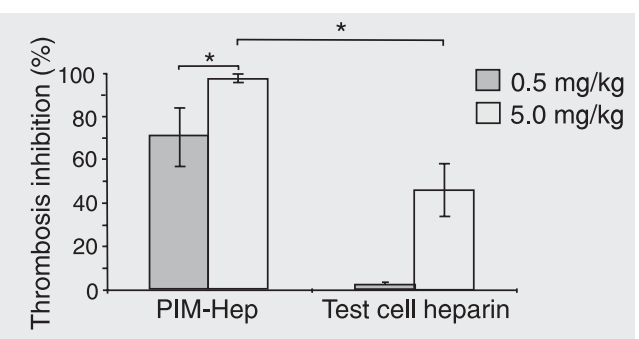

Figure 3. Antithrombotic activity of porcine heparin (PIM-Hep) or oocyte test cell heparin. Antithrombotic activity was determined using a stasis thrombosis model in rats after intravenous administration of the different heparins in a bolus (see Material and Methods). Mean thrombus weight was obtained for each group and then reported as percent weight in the absence of polysaccharide. Percent inhibition of thrombosis (mean $\pm \mathrm{SD}, \mathrm{N}=4$ ) is reported as a function of heparin concentration. ${ }^{*} \mathrm{P}<0.05$ for the comparisons indicated by the horizontal lines (Student $t$ test).

Table 1. Hemorrhagic effect of mammalian and oocyte test cell heparins.

\begin{tabular}{lc}
\hline Treatment & Blood loss $(\mu \mathrm{L})$ \\
\hline Saline & $32 \pm 5.5$ \\
Porcine heparin $(0.5 \mathrm{mg} / \mathrm{kg})$ & $21 \pm 5$ \\
Porcine heparin $(5.0 \mathrm{mg} / \mathrm{kg})$ & $87 \pm 19$ \\
Test cell heparin $(5.0 \mathrm{mg} / \mathrm{kg})$ & $36 \pm 6$ \\
\hline
\end{tabular}

Porcine heparin ( 0.5 or $5.0 \mathrm{mg} / \mathrm{kg}$ body weight) or oocyte test cell heparin $(5.0 \mathrm{mg} / \mathrm{kg}$ body weight) was administered intravenously in a bolus and allowed to circulate for $5 \mathrm{~min}$. The rat tail was cut 3 $\mathrm{mm}$ from the tip and immersed in $40 \mathrm{~mL}$ distilled water at room temperature. Blood was collected for $60 \mathrm{~min}$ and blood loss was determined by measuring the hemoglobin content of the water by spectrophotometry at $540 \mathrm{~nm}$ (14). Data are reported as means \pm SD for groups of 4 rats. 
Porcine heparin at a dose 10 times lower produced a 5 -fold increase in aPTT.

The antithrombotic activity of heparin is associated with its ability to induce inhibition of thrombin and factor Xa by antithrombin. It has been shown more recently in animal experiments that anti-factor Xa activity is a prerequisite, although not sufficient by itself, for a thrombosis-preventing effect (15-17). In fact, oocyte test cell heparin inhibited thrombosis to a much lesser extent than porcine heparin at the same dose. At the highest dose tested $(5 \mathrm{mg} / \mathrm{kg}$ body weight), test cell heparin inhibited thrombosis by only $45 \%$ compared to $100 \%$ inhibition obtained with the same dose of porcine heparin. This result is probably associated with the very low anti-IIa and anti-factor Xa activities of test cell heparin.

Usually, low-molecular weight heparins, that contain high anti-factor $\mathrm{Xa}$ and low anti-IIa activities, have a lower bleeding effect than unfractionated heparin (18-21). However, the mechanism by which heparins and other sulfated glycosaminoglycans contribute to bleeding is unknown. In a previous study (22), we demonstrated that there is a dissociation of the anticoagulant action, an- tithrombotic activity and bleeding effect in the case of other glycosaminoglycans. We showed that for dermatan sulfates with different sulfation patterns an increase in HCII activity does not result in a parallel increase of the antithrombotic potency or of the bleeding effect (22). Similarly, the effect of another class of sulfated polysaccharides, namely sulfated galactans, on coagulation, bleeding and thrombosis is also not coupled (23). On the other hand, our results regarding the effect of heparins on bleeding indicated that a reduction of the anticoagulant activity of heparin abolished its bleeding effect. However, significant antithrombotic activities (70 and $45 \%$ thrombin inhibition for mammalian and oocyte test cell heparin, respectively; Table 1) with no bleeding effect were observed even when oocyte test cell heparin was administered at high doses.

We have reported here the antithrombotic properties of a new heparin molecule from the oocyte test cells of S. plicata. Our results indicate that for this oocyte test cell heparin there is a parallelism between the anticoagulant and antithrombotic activities that are dissociated from the hemorrhagic effect.

\section{References}

1. Kjellén L, Lindahl U. Proteoglycans: structures and interactions. Annu Rev Biochem 1991; 60: 443-475.

2. Conrad HE. Heparin binding proteins. San Diego: Academic Press; 1998.

3. McLean J. The thromboplastic action of cephalin. Am J Physiol 1916; 41: 250-257.

4. Jordan RE, Oosta GM, Gardner WT, Rosenberg RD. The kinetics of hemostatic enzyme-antithrombin interactions in the presence of low molecular weight heparin. J Biol Chem 1980; 255: 10081-10090.

5. Leyvraz PF, Richard J, Bachmann F, Van Melle G, Treyvaud JM, Livio JJ, et al. Adjusted versus fixed-dose subcutaneous heparin in the prevention of deep-vein thrombosis after total hip replacement. N Engl J Med 1983; 309: 954-958.

6. Poller $\mathrm{L}$. Therapeutic ranges in anticoagulant administration. Br Med J 1985; 290: 1683-1686.

7. Straus $A H$, Nader HB, Dietrich CP. Absence of heparin or heparinlike compounds in mast-cell-free tissues and animals. Biochim Biophys Acta 1982; 717: 478-485.
8. Cassaro CM, Dietrich CP. Distribution of sulfated mucopolysaccharides in invertebrates. J Biol Chem 1977; 252: 2254-2261.

9. Medeiros GF, Mendes A, Castro RA, Bau EC, Nader HB, Dietrich $\mathrm{CP}$. Distribution of sulfated glycosaminoglycans in the animal kingdom: widespread occurrence of heparin-like compounds in invertebrates. Biochim Biophys Acta 2000; 1475: 287-294.

10. Burson SL, Fahrenbach MJ, Frommhagen LH, Riccardi BA, Brown RA, Brockman JA, et al. Isolation and purification of mactins heparin-like anticoagulants from mollusca. J Am Chem Soc 1956; 78 : 5874-5878.

11. Rahemtulla F, Lovtrup $S$. The comparative biochemistry of invertebrate mucopolysaccharides - VI. Crustacea. Comp Biochem Physiol B 1976; 53: 15-18.

12. Cavalcante MC, Allodi S, Valente AP, Straus AH, Takahashi HK, Mourao PA, et al. Occurrence of heparin in the invertebrate Styela plicata (Tunicata) is restricted to cell layers facing the outside environment. An ancient role in defense? J Biol Chem 2000; 275: 3618936196. 
13. Vogel GM, Meuleman DG, Bourgondien FG, Hobbelen PM. Comparison of two experimental thrombosis models in rats effects of four glycosaminoglycans. Thromb Res 1989; 54: 399-410.

14. Herbert JM, Héralt JP, Bernat A, Van Amsterdan RGM, Vogel GMT, Lormeau JC, et al. Biochemical and pharmacological properties of SANORG 32701. Comparison with the "synthetic pentasaccharide (SR 90107/org 31540)" and standard heparin. Circ Res 1996; 79: 590-600.

15. Holmer E, Mattsson C, Nilsson S. Anticoagulant and antithrombotic effects of heparin and low molecular weight heparin fragments in rabbits. Thromb Res 1982; 25: 475-485.

16. Thomas DP, Merton RE, Barrowcliffe TW, Thunberg L, Lindahl U. Effects of heparin oligosaccharides with high affinity for antithrombin III in experimental venous thrombosis. Thromb Haemost 1982; 47: 244-248.

17. Thomas DP, Merton RE, Gray E, Barrowcliffe TW. The relative antithrombotic effectiveness of heparin, a low molecular weight heparin, and a pentasaccharide fragment in an animal model. Thromb Haemost 1989; 61: 204-207.

18. Bagge L, Wahlberg T, Holmer E, Tyden H, Nystrom SO, Malm T.
Low-molecular-weight heparin (Fragmin) versus heparin for anticoagulation during cardiopulmonary bypass in open heart surgery, using a pig model. Blood Coagul Fibrinolysis 1994; 5: 265-272.

19. Colwell CW Jr. Recent advances in the use of low molecular weight heparins as prophylaxis for deep vein thrombosis. Orthopedics 1994; 17 (Suppl): 5-7.

20. Haas S, Flosbach CW. Prevention of postoperative thromboembolism with Enoxaparin in general surgery: a German multicenter trial. Semin Thromb Hemost 1993; 19 (Suppl 1): 164-173.

21. Hirsh J. Comparison of the relative efficacy and safety of low molecular weight heparin and unfractionated heparin for the treatment of venous thrombosis. Haemostasis 1996; 26 (Suppl 4): 189-198.

22. Vicente CP, Zancan P, Peixoto LL, ves-Sa R, Araujo FS, Mourao PA, et al. Unbalanced effects of dermatan sulfates with different sulfation patterns on coagulation, thrombosis and bleeding. Thromb Haemost 2001; 86: 1215-1220.

23. Farias WR, Nazareth RA, Mourao PA. Dual effects of sulfated Dgalactans from the red algae Botryocladia occidentalis preventing thrombosis and inducing platelet aggregation. Thromb Haemost 2001; 86: 1540-1546. 